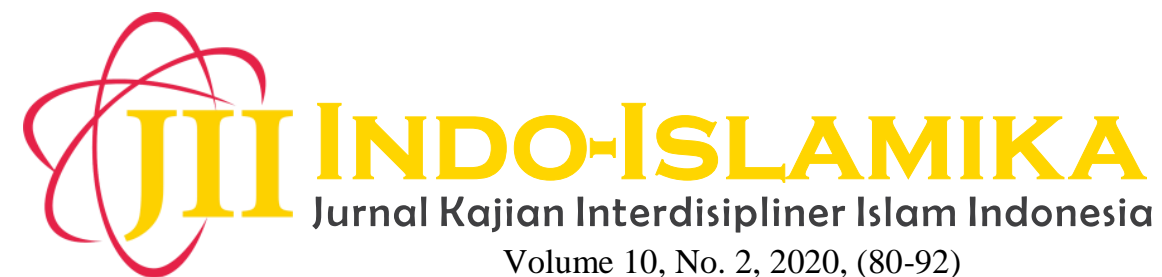

Sekretariat : Graduate School Syarif Hidayatullah State Islamic University (UIN) Jakarta

Website OJS : http://journal.uinjkt.ac.id/index.php/indo-islamika/index E-mail : indoislamika@uinjkt.ac.id

\title{
Annales Sect in Islamic Historical Research
}

\author{
Alvin Noor Sahab Rizal,1 Vivi Lutfiani² \\ ${ }^{1}$ Graduate School of UIN Syarif Hidayatullah Jakarta, Indonesia \\ 2Universitas Mercu Buana, Indonesia \\ Corresponding E-mail: alvin.noor18@mhs.uinjkt.ac.id
}

\begin{abstract}
There are many things we learn if we know about life landmark, which eventually will be the history of human's life. Similarly, the Islamic history and Islamic Historiography, which was developed at the same time with Muslim's development and does not separated from the general development of Islamic civilization. Historical method is the process of critically examining and recording of past recording and old heritage. The data obtained by this process of Past Imaginative reconstruction is known as Historiography. The aim of studying Islamic history is designed to broaden our understanding, to know an incredible fact that may not have been heard by people. By using this thinking framework the historians objectively guided to conduct their research.
\end{abstract}

Keywords: Method, History, Islam, Annales Sect

\begin{abstract}
Abstrak
Banyak hal yang kita pelajari jika kita mengetahui tentang tonggak kehidupan, yang pada akhirnya akan menjadi sejarah kehidupan manusia. Begitu pula dengan sejarah Islam dan Historiografi Islam, yang berkembang seiring dengan perkembangan umat Islam dan tidak lepas dari perkembangan umum peradaban Islam. Metode sejarah adalah proses pemeriksaan dan pencatatan secara kritis terhadap pencatatan masa lalu dan peninggalan kuno. Data yang diperoleh dari proses rekonstruksi Imajinatif Masa Lalu ini dikenal sebagai Historiografi. Tujuan mempelajari sejarah Islam dirancang untuk memperluas pemahaman kita, untuk mengetahui fakta luar biasa yang mungkin belum pernah didengar oleh orang-orang. Dengan menggunakan kerangka berpikir ini para sejarawan diarahkan secara obyektif untuk melakukan penelitiannya.
\end{abstract}

Kata Kunci: Metode, Sejarah, Islam, Mazhab Annales

\section{INTRODUCTION}

Writing is a culmination of everything, because anything what written is historyrecite (history as momentum). In the historical aspect the culture of reciprocation and relationship (interaction) or borrow to borrow concept between one culture to another is always happens, similar to what happens between West Culture with Islamic Civilization.

1 Taufik Abdullah and Abdurrachman Surjomiharjo, The Science of History and The Historiography of Sense and Perspective (Yogyakarta; Ombak, 2016), xv. 
In this process, there is acceptance and resistance behavior, but on the certain condition that the culture is more powerful than another. Ibn Khaldun said, "The citizens who were conquered by will tend to imitate the culture of their conquerors". Islam provides a system of help among people on the political, economic, social life, and even peace systems. Islam also triggers the covenant system, consulates, political asylum, and da'wah. As well as the collaboration and economic relations are allowed to use by others, such as Jews, Persians and Greeks. ${ }^{2}$

When Islamic Civilization changed greatly and dominated more in the Middle Ages, ${ }^{3}$ Europeans tend to imitate or "kiblah to Islam". Now when western culture turns to be more powerful and dominate, the possibility impersonation processes will also happens. It proven since the rise of the West civilization as well as the weakened political power of Islam, Muslim scientists learned a wide range of disciplines including Islam to the West in order to imitate its. It's just because Islamic Civilization is in the most popular condition, the ability to filter concepts on Western thinking and culture is also weak. ${ }^{4}$

Writing about the methodology of Islamic history conducted by a group or individual at a certain time, of course the aims is to share the historical development of classical era to this current time, both are in thought and in scientific approaches which was carried out by using the methodology of a person or group to receive something they need.

Related to the problem, the author will discuss related matters using Islamic historical methods. The author will discuss what the method in he history of Islam and how do Islamic historical methods contribute to the era development.

\section{The Definition of Method, History and Islam}

The method of Islamic history consists of three words, namely method, history, and Islam. The method comes from the Greek metodos, it consists of two syllables, and they are methe which means through or passing and hados which means way or manner. Therefore, methodology is a science or study that discusses the framework of concepts, manner or procedures, which means to analyze the principles or procedures that will lead, direct to the investigation and preparation of a field of science (in this term is the science of history, which is the reality of moments that happened in the past, to be prepared as a historical story). Thus, the methodology or science of methods is a science that reveals the manner. ${ }^{5}$

The History term comes from the Arabic word "Syajarah" means "The Tree". Prof. Azyumardi Azra tells the application of this word is related to two things: Firstly, because the verb "syajara" has a meaning of "to happen", "to occur", "to develop". Secondly, the history concern of "syajarat al-nasab", the term is defined as "family history". However, in its development, "history" is known a word that has a certain meaning similar to the words "istoria" (Greek), "tārīkh" (Arabic), "history" (English), which in simply meaning, "that is the moments involve the people in the past". ${ }^{6}$

\footnotetext{
${ }^{2}$ Ibnu Khaldun, Muqaddimah Ibn Khaldun (Jakarta: Pustaka Pirdaus, 2000), 30.

${ }^{3}$ Abduvahob Tukhtanzarov, "The Development of Islamic Civilization on The Land of Turon," International Journal of Discourse On Innovation, Integration And Education 1, (2020): 139-143.

${ }^{4}$ H. M Syakirin al-Ghazali, The History of Islamic Civilization (Surakarta: EFUDE Press, 2013),

${ }^{5}$ H. M Syakirin al-Ghazali, The History of Islamic Civilization (Surakarta: EFUDE Press, 2013), 18.

${ }^{6}$ Azyumardi Azra, Islamic Education: Tradition and Modernization towards New Millenniums (Jakarta: Logos Wacana Ilmu, 2002), 218.
} 
History also has the meaning of a reconstruction story or also a collective empirical symptom of the past. According to the content (subject matter), history is divided into three parts:

1. Era (classical, medieval, modern, and etc).

2. Regions (Europe, Asia, America, and etc).

3. Thematic (religion history, political history, art history and etc). ${ }^{7}$

According to Ibn Khaldun, history is a unique event of a time or generation. General study of the condition of nations, regions, and immemorial at that time, were a principle for historians. Most missions from history are built by that principle of events are clearly visible. ${ }^{8}$

If reviewed in the etymological sense of the various languages above it can be concluded that the understanding of history is not separated from time and event. Therefore, it is important to understand an event, and then thus historians made periodization to simplify the event. ${ }^{9}$ According to Kuntowijoyo, dividing history into periodization is important. By knowing the characteristics of an era or period, people will find the answer to the question: What is to done? ${ }^{10}$

According to Ibn Khaldun, the history needs to be considered as a branch of philosophy. Because, basically, in history is contained the meaning of seeking the truth and observation, an in-depth explanation of the origin and cause of the material, knowledge and understanding of the essence, substance, and cause of an event. ${ }^{11}$

History is so important to people, where in the Qur'an itself there are many stories of prophets and past figures containing lessons that can be guide or should be avoided by humans in nowadays or in the future. ${ }^{12}$

According to Kuntowijoyo, the historical method is the direction of implementation and technical instructions related to criticism, materials, presentation of history, and interpretation. ${ }^{13}$ According to Louis Gottschalk, the historical method is the process of analyzing and critically testing relics and past heritage. ${ }^{14}$

According to Lapidus, as quoted by Prof. Azyumardi Azra, the history of Islam is the history of communication between the world of daily reality and the realm of religious symbols; the history related to the interaction between Islamic values and the differentiation of Muslim communities historical experiences which interconnected. ${ }^{15}$

The method of writing Islamic history has experienced many differences and developments from time to time. It is also caused by the development of thoughts and demands to simplify and deepen history. From this, the development of Islamic history writing methods can still be used in this current time. The history recorded by historians with various methods of writing goes through various important things and events

7 Supiana, Methodology of Islamic Studies (Jakarta: Direktorat Jenderal Pendidikan Islam Departemen Agama Republik Indonesia, 2009), 74.

${ }^{8}$ Ibnu Khaldun, Muqaddimah Ibn Khaldun, 52.

${ }^{9}$ Novi Triana Habsari, "The Important sense of Historiography and Methodology in Historical Research," Journal of Agastya 6, 1 (2016): 56.

${ }^{10}$ Kuntowijoyo, Islam as a Knowledge: Epistemology, Methodology, and Etic (Yogyakarta: Tiara Wacana, 2006), 7.

${ }^{11}$ Ibn Khaldun, Muqaddimah Ibn Khaldun, 3.

${ }^{12}$ Dudung Abdurrahman, The Method of Historical Research ( Jakarta: Logos, 1999), 4.

${ }^{13}$ Kuntowijoyo, The Methodology of History (Yogyakarta: Tiara Wacana, 1994), xxi.

${ }^{14}$ Louis Gottchalk, Understanding History (Jakarta: UI-Press, 1969), 32.

15 Azyumardi Azra, Islamic Education: Tradition and Modernization towards New Millenniums, 221. 
concerning the development of Muslims. Moreover, Studying Islamic History and Historiography is beneficial.

Dr. Muhammad Amhazun said as quoted by Samsul Amir Munir ${ }^{16}$ that the history of Islam as a history of belief and religion, before becoming the history of the country, kingdom, and political rules. Because the belief that has built the system of society and country in terms of economic, political, social and others. Therefore, when learning history should be followed by the rules and views of syariah, which can explained the responsibilities and role of human in reforming the people and history in line with the will ilahiyah. The history of human being according to Islamic views is to spell out the will of rabbani. The Islamic method of interpreting history does not come out of aqidah in Islam and its built with akhlaq which makes it special from other historical movements with the influence of revelation.

In the early ages of Islam, people take a great attention in defending against enemy pressure and take an attention of the Islamic government. At that time, Muslims also take an attention to the teachings of the Qur'an. Another such as the history of Islamic victory and religious sciences such as fiqih and the others also received tremendous attention by Muslims. Various victories occurred in the early ages of Islam which certainly strengthened the Islamic government.

At that time, Muslims were relatively still less attentive to science. However, after the Abbasi government's policy with the support of extraordinary funds, the attention of Muslims began to be focused on various sciences and industries that were then widely controlled by non-Muslims. This situation makes the lives of Muslims better. The teaching of Islam and the Qur'an in terms of thought are perfect. Nevertheless, at that time Muslims continued to focus on studying thought, information, and civilization in other countries. Muslim historian Ibn Khaldun acknowledged that the curiosity of Muslims is derived from verses of the Qur'an and hadith that comprehensively encourage Muslims to master the knowledge. The first step taken by Muslims is to translate the works of civilization which at that time underwent a remarkable development in terms of his thinking. The translation activities of various advanced civilizations were quite significant, even at that time is well-known as the golden age of the translator movement. One of the most important works of the movement was Ibn Nadim, al-Fehrest. The book defines the science of the past and the scientific movement in the Islamic era until the fourth century of Hijriah. Since that time until now is rarely re-written the history of religious and national traditions. Ibn Qifthi's Akhbarul Ulama and Tabaqaatul Athibba' were the important among references to Islamic history. These works were largely defined by historical researchers. ${ }^{17}$

The hypothesis of Islamic historical methods is a procedure or systematic method by explaining the object of study to reconstruct the past of Islam. To achieve maximum results historians have made a real contribution to Islamic historical methods.

\footnotetext{
${ }^{16}$ Samsul Amir Munir, The History of Islamic Civilization (Jakarta: Amzah, 2009), 120.

${ }^{17}$ Cf. John H. Wigmore, Student's Texkbook of the Law of Evidence (Chicago, 1935), 225.
} 


\section{RESULT AND DISCUSSION}

\section{The Benefits of Learning Islamic Historical Methods}

\section{Inspirational Purpose}

Various historical stories can contribute inspiration to the listener and the reader. ${ }^{18}$ Learning from the national revival pioneered by the establishment of modern struggle organizations in the early 20th century; Indonesian society is now trying to develop a national revival and has been perceived as a result by society and academia.

\section{Educational Purpose}

Most of human being learns a lot from history, learns from the experiences he has done. Experiencing is not limited to his personal experience, but it can also be from previous generations. People through historical media can develop their potential, avoid the mistakes of the past starting from yourself or others.

\section{Recreation Purpose}

The usefulness of history as a story can provide a fresh entertainment, through the writing of historical stories that attract entertained readers. The lively and communicative writing style of some historians feels able to hypnotize the reader. Readers will feel comfortable reading the writings of historians. The consequences of the pleasure and appeal of writing a historical story make the reader happy. Reading becomes a medium of entertainment and reparative. Also reading has been perceived as a necessity, as the needs for recreation.

\section{Types of Islamic Historical Methods}

A known of history can be a representative to see the future. However, the reality of the future does not accordance with the something we expect. ${ }^{19}$

1. The historical approach according to Dr. Muhammad Amhazun mentions, that in historical studies there are at least use two methods. First: "Al-Tautsiq wa Itsbatul Haqaiq Method" and secondly "Al-Tafsir al-Tarikhi Method".

The first method is known as "historiography with history" which is a method that connects historical information with its sources that according to its current measurement can be seen as having fulfilled ideally in historical research and scientific thoroughness. 'Urwah ibn Zubayr and al-Thabari were the figures that developed this method. While the second method is known as "historiography with dirayat" is a historical method that takes an attention to knowledge directly from one side and rational interpretation from another perception. People who developed this method are al Mas'udi, Ibn Maskawaih and Ibn Khaldun.

\section{a. Historiography Method with History}

This method is a method of studying historical of sanad and matan that lay on to the correct nash and filtered news. That is, by linking history with one of the branches of hadith called the science of Jarh wa Ta'dil, which discusses the biography, characteristics, akhlaq, and aqidah of a rawi.

With the support of the books on the rules of narration in the science of Jarh wa Ta'dil it is very useful to delve into history as deeply as it can. With these rules will be revealed the state of the rawi which is useful to distinguish which is strong, which is weak, which is honest and which is lying. By this principle will

\footnotetext{
${ }^{18}$ Solihah Titin Sumanti, dkk, "Islamic Organizations in North Sumatra A Historical Analysis on Newspaper Publication in 1915-1942," (2019): 44-47.

${ }^{19}$ Abd. Rosyad Shaleh, Manajemen of Dakwah Islam (Jakarta: CV. Bulan Bintang, 1997), 60.
} 
be noticed which the correct news or hasan and avoid the dhaif principle or maudhu'. Moreover, the aim of historical study is to define the substance of history.

As for the hadith experts who have concerns about the sirah nabawiyah are Abban ibn Utsman, Urwah ibn Zubair ibn Awam, Ashim ibn Umar bin Qatadah, Muhammad bin Muslim bin Syihab al-Zuhri, Musa ibn Uqbah, Ma'mar ibn Rasyid, Muhammad ibn Ishaq. There are also historians who have historical histories such as Muhammad ibn Saib al-Kalbi, Awwanah ibn al-Hakam, Abu Mikhnaf Luth bin Yahya, Saif ibn Umar At-Tamimi, Haitsam ibn Adi and Nashr ibn Muzahim. From them then there are famous historians in Islam such as Khalifah ibn Khayath, Ibn Qutaibah, Al-Baladzari, Abu Hanifah Ad-Dainuri, AlYa'qubi, Al-Mas'udi and his Imam historian, Muhammad ibn Jarir al-Thabari. Since then the writing of the history of the Prophet Muhammad SAW began to progress which is the majority of the sources was news hadith from experts.

Imam al-Thabari is an Ulama who struggles with the method of al-Tautsiq wa Itsbat al-Haqaiq through his book Tarikh al-Rusul wa al-Mulk. In writing history he always applied:

1. Researching the Narration Path. One of the problems facing by the Muarikh (Historians) especially in this current time is that they are unable to distinguish the khabar or riwayat which true and false and they do not know the method of criticism of sanad as their predecessors. Imam al-Thabari has done all as he can to not to list the narration except the valid one, even if there is an incorrect riwayat, it is only nukhil from the opinion before him, if indeed he does not know the origin of the riwayat.

2. Research the texts. ${ }^{20}$

3. Stand on only to the Syar'i sources, the Quran and the Sunnah. Both are reliable sources in history and trusted, the Qur'an reaches us by way of mutawatir and hadith reaches us in a very thorough way that has been made by hadith scholars.

In this dirayah method there are two sciences learned, namely the science of sanad and matan hadith.

1. Dirasatul Asnad (studying sanad or narration path).

Sanad is a language that is al-mu'tamad means trustworthy, and in the term is a perawi lineage that conveys the news from the individual to the history of the original source.

This method is used to agree on the validity of information, in the process of codification of the Prophet's SAW hadiths, this method has also been done so that the hadith collectors believe the connection of the sanad hadiths to the Prophet. This further explains that history follows the hadith method at the beginning of its recording, and even history takes the news from an authoritative historical sequence that is also taken from the hadith.

2. Dirasatul Matan (studying matan or content of hadith).

Matan which is what is conveyed fromsanad is a word or news, the object of this study includes; researching nash so as not to disqualifies, rules and urf (habits) of human being, investigating human knowledge and history, impossible things and others. The object can also be in the form of fiqh laws.

${ }^{20}$ Oliver Leaman and Seyyed Hossein Nasr, eds. History of Islamic philosophy. Routledge, 2020. 


\section{b. Historiography Method With Dirayat}

According to Badri Yatim, the dirayat historiography is a historical method that puts interesting to knowledge directly in one sense, and rational interpretation from another sense. This method complements the historiography method with the previous riwayat. This method takes a great attention to the content of historical texts derived, but the text was only received after through intellectual and rational criticism. ${ }^{21}$

Historians of this historiography with dirayat have a comprehensive historical insight, which is to takeattention to experience, evidence, and direct observation in addition to attention to the narrated riwayat. Hence, compared to riwayat historiography, dirayat historiography is completed with great attention to the variables that determine the motion of history. Thus, the Historians, the fourth and fifth centuries of Hijriah take more attention to the reality of human activities that they thought, affected by geographical, climatic, and social conditions.

2. Historical Methods according to Ibn Khaldun. That, Historical studies are studies that discuss the relationship between different moments and different events, so that it is clear the driving factor, the point of rejection and its value, in order to find the lessons and ibrah of the event. Ibn Khaldun's definition above is an exact historical definition, because it mentions the importance of researching the validity of the news and examining the cause or illah of the moment. From this sense, history is no longer considered just a moment, but also an interpretation of it. Moreover, history becomes one of the weapons to start a thought, spread and defend the mind as history also plays a role in theological debate between peoples and nations.

3. The historical approach according to Husen Naser are:

a. Idealism Approach is a researcher who seeks to understand and interpret historical facts by believing in the full facts without any doubt.

b. Reductionist approach is a researcher who tries to understand and interpret historical facts with doubt.

c. Diachronic is a search of the history and development of one phenomenon under investigation.

d. Synchronic is the contextualization or sociological life which round of the phenomenon that is being studied.

e. Theory is a study that covered the background and development of a complete phenomenon with socio-historical history and cultural values surrounding it. $^{22}$

4. The method of history according to Kuntowijoyo in his book "The History Approach" is approach history is essentially an attempt to see the past through the present. Here's a method of approaching history:

a. The selection of topics, in the context of Islamic studies can mean the selection of Islamic phenomena and religious issues.

${ }^{21}$ Badri Yatim, The History of Islamic Civilization: Dirasah Islamiyah II (Jakarta: Raja Grafindo Persada, 1993), 52.

${ }^{22}$ Khoirudin Nasution, The Introduction of Islamic Studies (Yogyakarta : 2009), 223-224. 
b. Collection of sources, such as written documents, artifacts, oral sources, etc. In the context of Islamic studies means the collection of nash Al Qur'an or sunnah related to the topic.

c. Verification, proof, historical criticism, validity of the source, its authenticity, etc. In the context of Islamic studies can mean the reading of asbabun nuzul or asbabul wurud the nash related to the topic.

d. Interpretation, analysis and interpretation. Interpretation of topic issues.

e. Writing conclusions, interpretation results to apply. ${ }^{23}$

5. The historical approach is generally divided into four:

1. Heuristics (Source Collection)

The source of history is everything that directly or indirectly concerns us about a human reality or activity in the past (past actuality). Historical sources are historical raw materials that include all sorts of evidence that have been left by humans that show all their activities in the past in the form of written words or spoken words. ${ }^{24}$

2. Source Criticism (External/Material and Internal/Content)

Once the historical sources in the various categories are collected, the next stage is verification or commonly referred to as criticism to obtain the validity of the source.

When seeking the truth, historians are faced with the need to tell what is right, what is not true, what is possible and what is doubtful or impossible. In order to decide this, all historians must exert all the abilities of his mind, even often he must combine knowledge, doubt, believe, and use common sense. This is the function of criticism so that historical works are the product of a responsible scientific process, not the result of a fantasy, manipulation or fabrication of historian. ${ }^{25}$

Historical criticism is distinguished by two kinds, it are external criticism and internal criticism. ${ }^{26}$ First, external criticism, external criticism is a way of verifying or testing aspects outside of historical sources. at least five questions must be answered satisfactorily, they are:

a. Who said that?

b. Has by one way or another that testimony been altered?

c. What exactly does that person mean by his evidence?

d. Does the person who bears witness be a competent eyewitness, does he know that fact?

e. Did the witness tell us the truth and give us that known fact? ${ }^{27}$

Second, internal criticism, this criticism emphasizes to the inside aspect, which is the content of the testimony source. After the fact of testimony is upheld through external criticism it is the historian's turn to conduct an evaluation of the testimony. This decision is based on two investigations (inquiry), as follow:

First, the true meaning of that testimony must be understood. What exactly does the author want to say? It is impossible to evaluate a testimony, unless someone knows clearly what has been said. Something that has been said is not always clear so it is not

${ }^{23}$ Ahmad Ali Riyadi, Understanding of the Methodology of Islamic Studies (Yogyakarta: Teras, 2013), 93 .

${ }^{24}$ Helius Sjamsuddin, The Methodology of History, 95.

${ }^{25}$ Helius Sjamsuddin, The Methodology of History, 103.

${ }^{26}$ Muhammad Arif, Introduction of Historical Studies (Bandung: Yrama Widya, 2011), 38

${ }^{27}$ Helius Sjamsuddin, Methodology of History, 104. 
easy to understand what the real intent is. Second, after the facts and testimony are proven and once the true meaning of its contents has been very clear, then the credibility of evidence must be established. The witness or author must clearly show competence and truth. A researcher should be able to be fixed of the moral values and honesty of the witness and that he is telling the truth about the events he observed at the time in the sense of not deceiving historians. So, it is the duty of internal criticism to uphold these facts. ${ }^{28}$

\section{Interpretation}

Interpretation is often referred to as "source" subjectivity. ${ }^{29}$ On the one hand this statement is true because without the interpretation of historians, the data cannot "speak". According to Leopold Van Ranke, it is thought that the whole thing should be written as it actually is. That is, historians must submit to facts, historians must have integrity, so as to approach the direction of truth. ${ }^{30}$

4. Historiography (historical writing).

Writing history is an intellectual activity and a major way to understand history. When the historian start to the writing stage, he exerted all his mind power, not only the technical skill of using quotations and notes, but primarily the use of critical thoughts and analysis because he would eventually produce a synthesis of all his research or his discovery in a whole writing called historiography. The significance of all the facts collected through the new method of criticism can be understood in relation to each other after everything is written in one round wholeness of historiography. ${ }^{31}$ An important aspect of historiography according to the Annales sect is the study of the past to fulfill the social functions of the present. ${ }^{32}$

According to Ibn Khaldun, there are reasons for the error in the writing of history made by historians. ${ }^{33}$

1. Impartiality of a belief or opinion. To write a history, historians must be in a neutral state. If historians lean more towards one source and another is ignored then there will be errors in the writing.

2. Excessive trust in the source. Historians should not believe fully in the source, because it is not always the source revealing the facts that are actually happening. Therefore, historians must have many sources, in order to know who is right and who is wrong. Usually the source will be more favored. Historians are also required to obtain a neutral speaker so as not to side.

3. Inability to understand what it really means. Means, historians do not understand the explanation of the source, or from the notes he has written.

4. Historians give unwarranted assumptions to news sources. Means, historians explain the wrong news, but the historian considers it as the right thing.

5. Historian's ignorance in matching circumstances with actual events. Usually this happens because the historian is satisfied to have described the events

\footnotetext{
${ }^{28}$ Helius Sjamsuddin, Methodology of History, 112-113.

${ }^{29}$ Andrew C. Miller, Abbas M. Khan, dan Amir Vahedian-Azimi, "Clarification on Islamic Jurisprudence and Transplantation," Transplantation Direct 6, 8 (2020).

${ }^{30}$ Kuntowijoyo, Historical Explanation (Yogyakarta: Tiara Wacana, 2008), 35.

${ }^{31}$ Helius Sjamsuddin, Methodology of History, 153.

32 Azyumardi Azra, "Islam in the "Land under the Wind" in the Trade Period," Journal of Islamika 3, 2 (1996): 199.

${ }^{33}$ Dudung Abdurrahman, Method of Historical Research, 6.
} 
that have been seen only, but inadvertently the historian describes the wrong news because he only sees and concludes for himself what has happened.

6. The desire to take the hearts of high-ranking people. Usually by doing praise, taking good every deed of the ruler, and approaching the ruler for a certain purpose until there is a lie then in the writing of history is wrong.

7. Not knowing the disposition of various conditions that arise in civilization. Basically every natural phenomenon as well as a social phenomenon, has its law of control. This law, the historians must know in order to distinguish between news that is false or not.

\section{Annales Sect in Islamic History Research}

According to Febvre, history is a total effort by using all social sciences to collect as much data as possible and by digging and filtering through the entire heritage of past societies, for the organization of facts. This is important on at least two things: first, in explaining or making facts and reasonable data; second, in fulfilling the social function of writing history itself. Without "organizing", then facts and even the past become heavy burden that incriminate the present. ${ }^{34}$

Braudel's main historical agenda is essentially the unification of historical and social studies. His point of view is based on the basic task of history is to examine the reciprocal relationship between individuals and society. Historians should place his work in his social environment. Therefore, the methods used by historians must be psychological in nature and the mentality of past epics should be investigated more historically-psychologically than cooperatively. ${ }^{35}$

Social history refers to three forms of history: first, it refers to the history of the "poor people" or the lower class, or more emphatically, the history of the poor movement. The most prominent example of Indonesian history is Sartono Kartodirjo's "The Rebellion of Banten Farmers in 1888". Although Kartodirjo discusses "farmers", the prominent portrait in his social movement is precisely the Islamic movement at that level, which in this case many Sufis and thariqah represented. Second, social history refers to "historical" studies that are difficult to classify expressly, but generally concern "ordinances", customs, and daily life. Third, social history is associated combined with "economic history". 36

Most of the history of Islamic culture that developed is the history of the Muslim dynasties and the fall of the Muslim Dynasties, ${ }^{37}$ from the beginning of Islam until the independence of the Muslim States after the World War II. More narrowly, the history of Islamic culture is the history of the historical elite of Muslim rulers. The discussion of non-political aspects has only a small share, such as the scientific movement in Abbasiyah era, but this is also more highlighted in terms of political development without considering the aspects of Muslim society's life more broaden. Therefore,

\footnotetext{
${ }^{34}$ Azyumardi Azra, "Islam in the "Land under the Wind" in the Trade Period," 1996, 199.

${ }^{35}$ Azyumardi Azra, "Islam in the "Land under the Wind" in the Trade Period," 198. Millenniums, 226.

36 Azyumardi Azra, Islamic Education: Tradition and Modernization towards New

37 On the other hand, culture is more likely to be understood as "art". Thus, the growing understanding of Islamic culture revolves around aspects of Islamic art, such as painting, calligraphy, and others. In fact, Islamic culture concerns very broad dimensions, which can briefly be said to concern almost all aspects of Muslim life. Read! Azyumardi Azra, Islamic Education: Tradition and Modernization towards New Millenniums, 219.
} 
according to Prof. Azyumardi Azra, the History of Islamic Culture is very "political oriented". This has implications for the emergence of inaccurate images of Islam and the Muslim community that they are more involved in endless power fights. In fact, in his perspective, Islamic History is not merely political history. Political history is a small part of Islamic history. The history of Islam intellectually covers social, cultural, economic, and educational life and intellectual traditions. ${ }^{38}$

In fact, in the growth of Islamic historiography since the early phases many related to and influenced by the development of siyasah among Muslims. Petersenquoting Prof. Azyumardi Azra in his study of the origin and growth of Islamic historical writing concluded that there is a very clear link between political-religious development and the establishment of Islamic historiography traditions. Taking the case of conflict and war between Ali ibn Abi Thalib and Muawiyah ibn Abi Sufyan, he proved that most of the historiography that emerged and developed along with the outbreak of al-fitnah al-kubrā among Muslims was written to defend and support certain political interests. This kind of historiography can be referred to as "partisan political historiography". ${ }^{39}$

To dispel this image, as the French Annales ${ }^{40}$ historian group proposes, political history should also provide an analysis of "long-term structures" (longe durée, longterm structures), which includes studies of various systems of "semeiological" ("semiology" = the study of signs and symbols) that belong to political studies, such as terminology, rites, behavior, and political mental attitudes. ${ }^{41}$ Therefore, this politics should be used as part of "general history/total history". ${ }^{42}$

In discussing the various issues concerning the history of Muslim communities, Lapidus used two approaches: first, historical and evolutionary, which were used to examine the formation of Muslim societies and their changes throughout history; second, analytical and comparative, which is used to understand variations among the Muslim community. ${ }^{43}$

Laidus's approach is based on a number of historical and methodological assumptions: first assumptions, the history of the entire society can be presented within the framework of institutional systems. An institution whether dynastic, economic, family, or religious practice, is the activity of a person or group of people conducted in a polarized relationship with other human beings as defined and legitimized in the mental world of the participants.

The second assumption is that the history of Islamic societies can be expressed in terms of 4 basic forms of institutions: families, including kabilah, tribes, other small community groups; economic organization which the production and distribution of material goods; cultural and religious concepts of absolute values, goals of human life,

38 Azyumardi Azra, Islamic Education: Tradition and Modernization towards New Millenniums, 219.

39 Author Team, Contextual of Islamic Studies: 70 Years Prof. Dr. H. Munawir Sjadzali, MA (Jakarta: Paramadina, 1995), 453.

${ }^{40}$ The main ideas of the Annales sect include the following: The change in orientation of historical analysis from historical events to histoire-problem. The change from political history (the history of the famous people of treaties, wars) to the history of all human activities. To do both analyses, it is necessary to cooperate with other disciplines, such as geography, sociology, psychology, economics, linguistics, social anthropology, and others.. To : Helius Sjamsuddin, Methodology of History, 314-315

${ }^{41}$ Azyumardi Azra, Islamic Education: Tradition, 220.

${ }^{42}$ Azyumardi Azra, Islamic Education: Tradition, 220.

${ }^{43}$ Azyumardi Azra, Islamic Education: Tradition, 221-222. 
and collectivity built on these concepts and commitments; organizing power, conflict adjustment, and defense. These institutions have distinctive qualities in each society but are interconnected through certain patterns. ${ }^{44}$

The third assumption is that the characteristics of institutional patterns in Islamic society have their roots in the past. However, according to Prof. Azyumardi Azra, this third assumption, tends to bring historians to see the historical development of Muslim communities from the core (core) of Islam, Arabs said. In fact, according to Hodgson that the core of the Islamic World is not only about the Arab regions of the Middle East but also the whole Arab World. ${ }^{45}$

This view-borrowing the term Prof. Azyumardi Azra-Arabic Core Oriented, illustrates the history of Islam as the growth of a single Nucleus, which then spreads and merges into institutions labeled "Caliphate". This "Arabic Core Oriented" match causes distortions to Islamic history when Western historians tend to look at the Islamic World, for example, from the windows of Baghdad, Cairo, or Damascus. This is where there is a view that considers Muslim communities outside the region, especially those in the Indian Subcontinent, Southeast Asia or West Africa, not included in the "great tradition" of Islam and Muslims in the Middle East. ${ }^{46}$

The view of this "center", according to Ricard W. Vulliet, is incapable of answering a number of questions, for example: Why is it that the majorities of Muslims is non-Arab communities and are outside the Arab region? Although Muslims are ethnically diverse, why are they able to develop a relatively coherent and homogeneous culture or civilization ${ }^{47}$

To complete this historical view of the "center", a historical view of the "edge" ("fringe"-not in a geographical sense) is required. If the view of the "center" begins from the political institution (caliphate) from the beginning of its growth, its extraordinary expanses, to its deterioration and destruction. Meanwhile, the history of the "edge" on the contrary, the history begins with individuals and small communities, spread over a very wide area but not well integrated, who speak different languages and who thrive in the heritage of diverse cultural and religious traditions. ${ }^{48}$

\section{CONCLUSION}

The history of Islamic civilization is news or stories of previous events about society, economy, technology, politics, social, etc. We can take a lesson that teaches it is a new life to create a young Islam or a wider one. So it cannot be denied that the history of Islamic civilization has contributed many benefits to what has been left behind.

Writing about historiography carried out by a group or individual in a certain period is to show the development of historical concepts both in thought and in the scientific approach used with a description of the growth, development and decline of the forms of expression used in the presentation of historical materials.

\footnotetext{
${ }^{44}$ Azyumardi Azra, Islamic Education: Tradition, 222.

${ }^{45}$ Azyumardi Azra, Islamic Education: Tradition, 222.

${ }^{46}$ Azyumardi Azra, Islamic Education: Tradition, 223.

${ }^{47}$ Azyumardi Azra, Islamic Education: Tradition, 223.

${ }^{48}$ Azyumardi Azra, Islamic Education: Tradition, 223.
} 


\section{REFERENCES}

Abdullah, Taufik and Abdurrachman Surjomiharjo. Studies of History and Historiography of sense and perspective. Yogyakarta: Ombak. 2016.

Abdurrahman, Dudung. The Method of Historical Research. Jakarta: Logos. 1999.

Alfian, Ibrahim. Bunga Rampai The Method of Historical Studies. Yogyakarta. Lembal Research and Survey 1AlN Sunan Kalijog. 1983.

Ali, Ahmad Riyadi. Understanding Methodology of Islamic Studies. Yogyakarta: Teras. 2013.

Amir, Samsul Munir. The History of Islamic Civilization. Jakarta: Amzah. 2009.

Arif, Muhammad. Introduction of Historical Studies. Bandung: Yrama Widya. 2011.

Azra, Azyumardi. Islamic Education: Tradition and Modernization towards New Millenniums. Jakarta: Logos Wacana Ilmu. 2002.

Azra, Azyumardi. "Islam in the "Land under the Wind" in the Trade Period." Jurnal Islamika 3, 2 (1996).

Gottchalk, Louis. Understanding of History. Jakarta: UI-Press. 1969.

Khaldun, Ibnu. Muqaddimah Ibn Khaldun. Jakarta: Pustaka Pirdaus. 2000.

Kuntowijoyo. Islam as Knowledge: Epistemology, Methodology, and Etic. Yogyakarta: Tiara Wacana. 2006.

Kuntowijoyo. Historical Methodology. Yogyakarta: Tiara Wacana. 1994.

Kuntowijoyo. Historical Explanatio. Yogyakarta: Tiara Wacana. 2008.

Habsari, Novi Triana. "The Significance of Historiography and Methodology In Historical Research." Journal of Agastya 6, 1 (2016).

H Wigmore, Cf. John. Student's Texkbook of the Law of Evidence. Chicago. 1935.

Leaman, Oliver, and Seyyed Hossein Nasr, eds. History of Islamic philosophy. Routledge, 2020.

Miller, Andrew C., Abbas M. Khan, and Amir Vahedian-Azimi. "Clarification on Islamic Jurisprudence and Transplantation." Transplantation Direct 6, 8 (2020).

Nasution, Khoirudin. Introduction of Islamic Studies. Yogyakarta: 2009.

Rosenthal, Franz. A History Of Muslim Historiography. Leiden. E.J Brill. 1968.

Rosyad, Abd Shaleh. Manajemen of Dakwah Islam. Jakarta: CV. Bulan Bintang. 1997.

Sjamsuddin, Helius. Historical Methodology. Yogyakarta: Ombak. 2012.

Sumanti, Solihah Titin, dkk. "Islamic Organizations in North Sumatra A Historical Analysis on Newspaper Publication in 1915-1942." 2019.

Supiana. Methodology of Islamic Studies. Jakarta. Direktorat Jenderal Pendidikan Islam Departemen Agama Republik Indonesia. 2009.

Syakirin, H. M al-Ghazali. History of Islamic Civilization. Surakarta. EFUDE Press. 2013.

Author Team. Contextualization of Islamic Studies: 70 Years Prof.Dr.H. Munawir Sjadzali, MA. Jakarta: Paramadina. 1995.

Triana, Novi Habsari. "The Significance of Historiography and Methodology In Historical Research." Journal of Agastya 6, 1 (2016).

Yatim, Badri. History of Islamic Civilization: Dirasah Islamiyah II. Jakarta: Raja Grafindo Persada. 1993.

Tukhtanzarov, Abduvahob. "The Development of Islamic Civilization on The Land of Turon." International Journal of Discourse On Innovation, Integration And Education, 1 (2020). 